\title{
Germination, growth and biochemical responses of papaya (Carica papaya L.) to electric field
}

\begin{abstract}
Electric field, a non-ionizing radiation, exists in abundant in the vicinity of high voltage power lines, covers a large area of the agricultural land and affects crop productivity. In this study, an attempt was made to unravel the potential of using electric field as an agricultural tool to increase seed germination and plant vigour, and to investigate the effect of electric field seed treatment of several strengths on the germination rate, and the subsequent growth and biochemical changes of papaya (Carica papaya L.) Eksotika II. Papaya seeds were subjected to electric field of different strengths such as 0 (control), 10, 20, 40, 60, 80, 100 and $120 \mathrm{kV} / \mathrm{m}$ prior to sowing. Electric field treatments exerted some influence on the growth and biochemical changes in papaya. Highest germination percentage occurred when seeds were treated with $60 \mathrm{kV} / \mathrm{m}$ electric field. Most of the electric field treatments resulted in higher shoot and root length and dry weight, but $120 \mathrm{kV} / \mathrm{m}$ resulted in negative growth responses. In terms of the biochemical responses of papaya, electric field treatments up to $40 \mathrm{kV} / \mathrm{m}$ yielded higher soluble protein and nitrogen content compared to control. Total chlorophyll and carotenoid content and peroxidase specific enzyme activity were also positively influenced by electric field treatment up to $100 \mathrm{kV} / \mathrm{m}$. Therefore, $60 \mathrm{kV} / \mathrm{m}$ may be considered as the optimum electric field strength for seed treatment to increase the germination, growth and biochemical quality of papaya.
\end{abstract}

Keyword: Chlorophyll; Electric field; Germination; Papaya; Peroxidase enzyme; Soluble protein 